\title{
Effects of a xylanase and beta-glucanase enzyme combination on growth performance of broilers fed maize-soybean meal-based diets
}

\author{
S. Gilani ${ }^{1 *}$, M.I. Gracia ${ }^{2}$, L. Barnard ${ }^{1}$, Y. Dersjant-Li ${ }^{1}$, C. Millán ${ }^{2}$ and K. Gibbs ${ }^{1}$ \\ ${ }^{1}$ Danisco Animal Nutrition (IFF), Willem Einthovenstraat 4, 2342 BH Oegstgeest, the Netherlands; ${ }^{2}$ IMASDE Agroalimentaria, \\ S.L.C/ Nápoles 3, 28224 Pozuelo de Alarcón, Madrid, Spain; saad.gilani@iff.com
}

Received: 26 April 2021 / Accepted: 8 June 2021

(c) 2021 S. Gilani et al.

RESEARCH ARTICLE

POULTRY

\begin{abstract}
The following study evaluated effects of a xylanase and beta-glucanase combination on growth performance of broilers fed energy reduced versus nutritionally adequate maize-soybean meal-based diets. A total of 648, one-day-old male broilers (Ross 308) were assigned to floor-pens ( $24 \mathrm{birds} / \mathrm{pen}$, nine pens/treatment, three treatments) in a randomised block design. Treatments included: (1) a nutritionally adequate positive control diet (PC); (2) a negative control (NC) diet in which energy, crude protein and digestible amino acids were reduced by $3.4 \%$ (-105 kcal apparent metabolisable energy), $2.3 \%$ and 1.2 to $3.0 \%$ vs PC, respectively; and (3) NC plus a xylanase and beta-glucanase combination that supplied 1,220 U xylanase and $152 \mathrm{U}$ beta-glucanase per kilogram of final feed. All diets contained a background of $500 \mathrm{FTU} / \mathrm{kg}$ phytase and were offered to birds ad libitum. Birds fed NC showed reduced average daily gain (ADG) by $-6.1 \%(P<0.05)$; increased feed conversion ratio (FCR) by 9.2 points $(P<0.05)$, and overall $(\mathrm{d} 1-35)$ body weight corrected FCR which was increased by 9.4 points $(P<0.05)$ vs the PC group. Enzyme supplementation increased final BW $(+4.2 \%, P<0.05)$, ADG $(+5.4 \%, P<0.05)$ and tended to reduce FCR $(+7.5$ points, $P=0.054)$ from d $22-35$ vs $\mathrm{NC}$, without affecting average daily feed intake. Improvements in performance due to the enzyme combination were equivalent to performance on the PC diet in all cases. The results suggested that significant improvements in growth performance of broilers fed maize-soybean meal-based diets which had been reduced in energy and nutrients can be realised by supplementation with xylanase in combination with beta-glucanase.
\end{abstract}

Keywords: non-starch polysaccharide, feed conversion ratio, nutrition, poultry

\section{Introduction}

Viscous cereal grains, such as wheat, that form the basis of commercial broiler diets, are high in non-starch polysaccharides (NSPs), which typically comprise 9 to $10 \%$ total NSPs compared to 8 to $9 \%$ (Choct, 2006) in maize (Zea mays), but levels are considerably higher (19 to $23 \%$ total NSP) in industrial by-products such as distillers dried grains with solubles (DDGS) (Widyaratne and Zijlstra, 2007). These NSPs are often complexed with other nutrients in the ingredient matrix and are not readily digested by endogenous enzymes. There is substantial evidence that has demonstrated the antinutritive effect of NSPs. In particular, the soluble NSP fraction has been shown to impair nutrient digestion and growth performance (Annison and Choct, 1991; Bao et al., 2013) by increasing digesta viscosity which impedes nutrient absorption (Annison and Choct, 1991; Bach Knudsen, 2011; Choct et al., 1996). In addition, complexing NSPs with other nutrients reduces digestibility (Choct et al., 2010) and the presence of NSP in the digesta can disrupt the composition of the gut microflora (Hubener et al., 2002) which can alter nutrient availability and utilisation.

Exogenous carbohydrase enzymes, including xylanases and $\beta$-glucanases, hydrolyse different substrates within the NSP fraction and have been developed to reduce such anti-nutritive effects and improve digestion and growth 
performance. These are routinely used in wheat-based broiler feeds, as there is widespread evidence demonstrating the efficacy of xylanase, and, to a lesser extent, $\beta$-glucanase, beyond the benefits delivered by the now almost ubiquitous use of phytase (Kiarie et al., 2014; Meng et al., 2005; Munyaka et al., 2016; Olukosi et al., 2007; Selle et al., 2009) and $\beta$-glucanase has been shown to be effective in diets containing barley (Mathlouthi et al., 2003; Jozefiak et al., 2006). The inclusion of these enzymes can support a more competitive use of less costly feed ingredients, whilst maintaining performance.

The application of xylanase to diets based on maize-soybean meal has been less well studied and evidence for beneficial effects is generally of a lower magnitude and less consistent than seen for wheat (Adeola and Cowieson, 2011; Kiarie et al., 2014; Masey O'Neill et al., 2012). This may be due to the complex nature of NSP in maize, as recently reviewed by Ward (2021). When selecting enzymes for use in broiler diets, it is important to consider the specific substrates present and their accessibility, as this is likely to influence efficacy. In wheat, the major NSPs are arabinoxylans (pentosans; principally xylose and arabinose) and to a lesser extent beta-glucans and cellulose, (Choct, 2006). In maize, the NSP profile is markedly different: Maize grains contain a lower concentration of the anti-nutritive soluble NSPs than wheat, principally soluble arabinoxylans that are the substrate for xylanases, as well as a higher content of insoluble NSPs and little, if any, beta-glucan presence (Choct, 2006). This indicates reduced availability of suitable substrates for xylanase and beta-glucanase compared with wheat, which has been suggested as a reason for the generally lower magnitude of broiler responses to carbohydrases reported for maize-based diets (Cowieson et al., 2010). However, soybean meal has a higher NSP content than either maize or wheat (approximately 14.5\%; Huisman et al., 1998) and contains a different carbohydrate polymer profile, being rich in pectic polysaccharides, xylans, arabinoxylans and xyloglucans. These polysaccharides are major components of the insoluble NSP fraction of soybeans, which are contained within the hemicellulose fraction of the cell walls (Huisman et al. 2000; McNab and Boorman, 2002; Ward, 2021) and are the major substrates for xylanase and beta-glucanase enzymes; Choct (2006) reported the total NSP content of soybean as $19.2 \%$ of dry matter, which included $1.8 \%$ xylose (of which $1.7 \%$ was insoluble), $2.9 \%$ arabinose (of which $2.4 \%$ was insoluble) and $0.5 \%$ glucose monomers (of which $0.3 \%$ was insoluble). Additionally, soybean meal typically contains $14.67 \%$ total NSP, $3.7 \%$ total arabinoxylans and $0.38 \%$ soluble $\beta$-glucans (Danisco Animal Nutrition Database, not publicly available).

Against this background, it is plausible that the application of a combination of xylanase and $\beta$-glucanase enzymes to maize-soybean meal-based diets may be effective in delivering improvements in digestibility and/or performance.
The present study investigated the effect of a commercially available xylanase- $\beta$-glucanase combination known to be effective in wheat-based diets (Munyaka et al., 2016), on growth performance of broilers fed a maize-soybean meal-based diet and containing full fat soybean meal. The enzyme combination was applied to a basal diet containing a moderate reduction in crude protein, energy and digestible amino acids, to determine whether the enzyme combination could recover performance compared with the level produced by a nutritionally adequate diet.

\section{Materials and methods}

The experimental procedures were carried out in compliance with the quality control requirements of IMASDE Agroalimentaria S.L., Madrid, Spain and principles of GCP (2000) Guidelines on Good Clinical Practice for Clinical Trials for Registration of Veterinary Medicinal Products (VICH), and to meet appropriate current quality standards indicated by EFSA (guidance for applicants on the presentation of applications for the request of authorisation of additives for use in animal nutrition).

\section{Experimental and control diets}

Positive control (PC) diets, based on maize and full-fat soybean meal, were formulated by feeding phase to meet the recommended requirements for nutrients of the birds during starter (d 1 to 21 ) and finisher (d 22 to 35 ) periods (Aviagen, 2014; Table 1) with slight modification to accommodate two instead of three phases. A negative control diet, containing moderate reductions in energy, crude protein and digestible amino acid content (-3.4\% or $105 \mathrm{kcal}$ apparent metabolisable energy (AMEn), -2.3\% and -1.2 to $-3.0 \%$ vs $\mathrm{PC}$, respectively) was formulated (NC; Table 1). Both the NC and PC diets were tested against an experimental diet formed from the $\mathrm{NC}$ plus a commercial xylanase and $\beta$-glucanase enzyme combination (NC+XB; Axtra ${ }^{\oplus B}$, Danisco Animal Nutrition, Leiden, the Netherlands) supplemented at $100 \mathrm{~g} / \mathrm{t}$ to provide $1,220 \mathrm{U} / \mathrm{kg}$ xylanase and $152 \mathrm{U} / \mathrm{kg}$ beta-glucanase in feed. The enzyme combination was a co-granule produced by Trichoderma reesei fermentation of endo-1,4-beta xylanase (EC 3.2.1.8) and endo-1,3(4) - beta glucanase (EC 3.2.1.6). All diets contained $500 \mathrm{FTU} / \mathrm{kg}$ of a commercial Buttiauxella spp. phytase, expressed in T. reesei (Axtra PHY, Danisco Animal Nutrition). Mash diets and water were provided to birds ad libitum for the duration of the study (d 1-35).

\section{Animals, housing and experimental design}

Six hundred and forty-eight male broilers (Ross 308) were obtained on day of hatch from a commercial hatchery, vaccinated against coccidiosis via drinking water and assigned to floor pens based on body weight (BW), so that each pen contained birds of approximately equal 
Table 1. Ingredient and calculated nutritional composition of the control diets ( $\mathrm{g} / \mathrm{kg}$, as fed basis). ${ }^{1}$

\begin{tabular}{|c|c|c|c|c|}
\hline \multirow[t]{2}{*}{ Ingredient (g/kg) } & \multicolumn{2}{|c|}{ Starter (d 0-21) } & \multicolumn{2}{|c|}{ Finisher (d 22-35) } \\
\hline & $\mathrm{PC}$ & NC & $\mathrm{PC}$ & NC \\
\hline Corn & 536.32 & 575.54 & 579.38 & 616.08 \\
\hline Soybean meal (48\% CP) & 305.35 & 305.88 & 258.76 & 242.86 \\
\hline Full fat soybean & 100.00 & 77.77 & 100.00 & 100.00 \\
\hline Soy oil & 20.83 & 3.00 & 28.89 & 7.59 \\
\hline L-lysine HCL & 1.56 & 1.82 & 1.20 & 1.48 \\
\hline DL-methionine & 3.28 & 3.26 & 2.61 & 2.61 \\
\hline L-threonine & 0.49 & 0.50 & 0.13 & 0.16 \\
\hline L-tryptophan & - & 0.03 & - & 0.04 \\
\hline Salt & 2.54 & 2.43 & 2.66 & 2.55 \\
\hline Sodium bicarbonate & 1.77 & 1.92 & 1.63 & 1.79 \\
\hline Limestone & 14.46 & 14.56 & 13.40 & 13.46 \\
\hline Monocalcium phosphate & 9.39 & 9.48 & 7.31 & 7.38 \\
\hline Vitamin-mineral premix ${ }^{3}$ & 4.00 & 4.00 & 4.00 & 4.00 \\
\hline \multicolumn{5}{|l|}{ Calculated nutrients ( $\mathrm{g} / \mathrm{kg}$ ) } \\
\hline Dry matter & 874.44 & 871.11 & 873.38 & 870.33 \\
\hline Crude protein & 220.00 & 214.94 & 200.00 & 195.29 \\
\hline Ether extract & 64.06 & 43.33 & 72.71 & 52.35 \\
\hline Crude fibre & 30.95 & 30.52 & 30.03 & 30.23 \\
\hline Starch & 324.39 & 347.89 & 350.08 & 372.10 \\
\hline Ash & 55.89 & 55.53 & 50.83 & 50.44 \\
\hline Calcium & 8.60 & 8.60 & 7.70 & 7.70 \\
\hline Total phosphorus & 5.98 & 5.98 & 5.32 & 5.32 \\
\hline Available $\mathrm{P}^{2}$ & 3.00 & 3.00 & 2.50 & 2.50 \\
\hline Sodium & 1.60 & 1.60 & 1.60 & 1.60 \\
\hline Chlorine & 2.20 & 2.20 & 2.20 & 2.20 \\
\hline AMEn, $\mathrm{kcal} / \mathrm{kg}$ & 3,050 & 2,946 & 3,150 & 3,044 \\
\hline Total lysine & 13.44 & 13.24 & 11.92 & 11.76 \\
\hline Total methionine & 6.68 & 6.66 & 5.78 & 5.72 \\
\hline Total methionine+cysteine & 10.25 & 10.12 & 9.08 & 8.97 \\
\hline Total threonine & 9.04 & 8.84 & 7.94 & 7.77 \\
\hline Total tryptophan & 2.73 & 2.68 & 2.47 & 2.43 \\
\hline Digestible lysine & 11.80 & 11.65 & 10.40 & 10.27 \\
\hline Digestible methionine & 6.27 & 6.21 & 5.39 & 5.34 \\
\hline Digestible methionine+cysteine & 9.20 & 9.09 & 8.10 & 8.00 \\
\hline Digestible threonine & 7.77 & 7.54 & 6.70 & 6.55 \\
\hline Digestible tryptophan & 2.32 & 2.28 & 2.09 & 2.06 \\
\hline
\end{tabular}

${ }^{1} \mathrm{AMEn}=$ apparent metabolisable energy; $\mathrm{CP}=$ crude protein; $\mathrm{NC}=$ negative control; $\mathrm{PC}=$ positive control.

${ }^{2}$ All diets contained 500 FTU/ kg phytase (Axtra PHY, a 6-phytase from Buttiauxella, Danisco Animal Nutrition, the Netherlands) which contributed 0.16\% AvP and $0.17 \% \mathrm{Ca}$. The total $\mathrm{Ca}$ and available $\mathrm{P}$ in the table showed the values without the contribution of phytase.

3 Supplied per kilogram diet: Vitamin A, 10,000 IU; Vitamin D3, 2,000 IU; Vitamin E (a-tocopherol), 30 mg; Vitamin K3, 2.0 mg; Vitamin B1, 2.0 mg; Vitamin B2, 5.0 mg; Vitamin B6, 3.0 mg; Vitamin B12, 12.0 mg; Nicotinic acid, 40 mg; Calcium pantothenate, 10 mg; Folic acid, 1.0 mg; Biotic, 0.1 mg; Choline chloride, 400 mg; $\mathrm{Cu}\left(\mathrm{CuSO}_{4} \times 5 \mathrm{H}_{2} \mathrm{O}\right), 8.0 \mathrm{mg} ; \mathrm{Fe}\left(\mathrm{FeCO}_{3}\right), 60 \mathrm{mg} ; \mathrm{I}(\mathrm{IK}), 2.0 \mathrm{mg} ; \mathrm{Mn}(\mathrm{MnO}), 70 \mathrm{mg} ; \mathrm{Se}\left(\mathrm{Na}_{2} \mathrm{SeO}_{3}\right), 0.15 \mathrm{mg} ; \mathrm{Zn}(\mathrm{ZnO}), 80 \mathrm{mg}$.

weight. There were 24 birds/pen and nine pens/dietary treatment arranged in a randomised block design. Pens were located in an environmentally controlled broiler house where temperature was initially maintained at $33-35{ }^{\circ} \mathrm{C}$, which was decreased by $3^{\circ} \mathrm{C}$ each week until d 28 , when the temperature was maintained at $22^{\circ} \mathrm{C}$. The lighting regime was LD 18:6 throughout the trial period.

\section{Measurements}

Body weight and feed intake (FI) were recorded on d 1, 7, 21 and 35 on a per pen basis and used to calculate average daily gain (ADG), average daily feed intake (ADFI) and feed conversion ratio (FCR). Mortality was recorded daily and used to correct FCR. European production efficiency factor (EPEF) was also calculated at $35 \mathrm{~d}$ as:
$\mathrm{EPEF}=($ mean daily gain $(\mathrm{g}) / \mathrm{FCR} \times 10) \times(100-\%$ mortality $)$

\section{Chemical analysis}

Proximate analysis of the diets, including dry matter (DM), crude protein (CP), fat (as ether extract), calcium, sodium and total phosphorus, were analysed by AOAC (2000) methods. Starch was analysed by polarimetric method and crude fibre (CF) by the Weende method. The results are shown in Table 2. Xylanase activity levels in feed were measured as a marker of enzyme presence in feed. Analysis was conducted in duplicate at the Danisco Animal Nutrition Biosciences Innovation Laboratories (Brabrand, Denmark), and reported as activity units, using the methods described by Romero et al. (2013) in Table 2. One xylanase unit (XU) was defined as the amount of enzyme that released 0.48 mmol of the reducing sugar xylose from wheat arabinoxylan 
per min at $\mathrm{pH} 4.2$ and $50{ }^{\circ} \mathrm{C}$. Xylanase activity was used as a marker for beta-glucanase activity in final feed samples.

\section{Statistical analysis}

Data were expressed on a per pen basis and subjected to analysis of variance (ANOVA) using the Fit Model platform of JMP 11.0 (SAS Institute Inc., Cary, NC, USA) to investigate the effects of treatment, with diet included as a fixed effect. The separation of mean was achieved using the Dunnett's test, with PC or NC as the control and $P$ values of the contrast between $\mathrm{PC}$ vs NC, phytase vs NC and phytase vs $P C$ presented. Differences were considered significant at $P \leq 0.05$ and a trend at $0.05<P<0.1$.

\section{Results and discussion}

No xylanase was recovered from the $\mathrm{NC}$ or PC diets. Xylanase values of $1,422 \mathrm{U} / \mathrm{kg}$ and $1,458 \mathrm{U} / \mathrm{kg}$ were recovered from starter and finisher $\mathrm{NC}+\mathrm{XB}$ feed samples, respectively. These were slightly higher $(<20 \%)$ than the target value of $1,220 \mathrm{U} / \mathrm{kg}$, but within an acceptable range.

The nutrient down-specification of the $\mathrm{NC}$ diet, with a reduction in the energy, crude protein and digestible amino acids, had no effect on performance during the starter phase, but reduced ADG $(-6.1 \%$ vs PC, $P<0.05)$ and increased FCR $(+9.2$ points vs $P C, P<0.05)$ during the early finisher phase ( $\mathrm{d} 22-35)$. There was a significant decrease in ADG for $\mathrm{NC}$ vs $\mathrm{PC}(P<0.05)$ and the corrected FCR was increased by +9.4 points $(P<0.05)$ overall $(\mathrm{d} 1-35)$. These results confirmed the negative effect of the nutrient reduced diet on performance, whereby birds were unable to compensate for the reduced energy and nutrients over the entire growth cycle (d 1-35). Cowieson et al. (2010) and Masey O'Neill et al. (2012) observed similar negative effects of reduced energy diets on FCR in maize-soybean meal-based diets over $42 \mathrm{~d}$, although these studies had some, limited, evidence of increased FI. In general, FCR for first seven days appeared high, however, this could have been be due to the use of mash diets which were slightly lower in protein (22\% NRC 1994 recommendations vs $23 \%$ recommended by Ross 308).

Feeding NC+XB had no effect on ADG, ADFI or FCR during the starter phase vs either the PC or NC (d 1-21) (Table 3). However, during the finisher phase (d 22-35), both $\mathrm{BW}$ and $\mathrm{ADG}$ were increased in the $\mathrm{NC}+\mathrm{XB}$ group vs the $\mathrm{NC}(P<0.05)$ by $4.2 \%$ and $5.4 \%$ respectively, to a level equivalent to the $\mathrm{PC}$-fed birds. The ADFI was unaffected during the finisher period, but there was a tendency for FCR being reduced $(P=0.07)$ compared to birds fed the PC diet. Overall (d 1-35), there was an improvement in mortalitycorrected FCR in birds fed NC+XB (-6.8 points vs NC, $P<0.05)$, and increased ADG $(+4.3 \%$ vs NC, $P=0.035)$ to the equivalent level of performance seen with the PC diet.

The EPEF (European production efficiency factor) was lower for $\mathrm{NC}$ compared to $\mathrm{PC}$, but was significantly improved $(P<0.05)$ with the $\mathrm{NC}+\mathrm{XB}$ diet. The major driver for the EPEF was better weight gain and similar feed intake for the $\mathrm{NC}+\mathrm{XB}$ group over those fed the $\mathrm{NC}$ diet.

As stated previously, a clear beneficial effect of exogenous xylanase in wheat-based diets on bird performance has been demonstrated in numerous previous studies (Adeola and Cowieson, 2011; Kiarie et al., 2014; Selle et al., 2009) although variation in responses existed due to factors such as differences in wheat cultivars, grain quality, processing and bird age/health (Amerah, 2015). In maize-based broiler diets, which typically contain significant quantities of soybean-meal, studies are limited, and the effects of xylanase supplementation have been generally reported to be lower in magnitude when compared to wheat-based diets (Kiarie et al., 2014; Munyaka et al., 2016). Munyaka et al. (2016) reported marked increases in BWG (+5.3\%) and reduced FCR $(-10 \%)$ by d 21 in broilers given maizesoybean meal or wheat-based diets supplemented with the

Table 2. Analysed chemical composition of diets and xylanase and phytase activity. ${ }^{1}$

\begin{tabular}{|c|c|c|c|c|c|c|}
\hline \multirow{2}{*}{$\begin{array}{l}\text { Parameter } \\
\% \text { or as fed }\end{array}$} & \multicolumn{3}{|c|}{ Starter 1-21 d } & \multicolumn{3}{|c|}{ Finisher 22-35 d } \\
\hline & $\mathrm{PC}$ & NC & $\mathrm{NC}+\mathrm{XB}^{2}$ & $\mathrm{PC}$ & NC & $\mathrm{NC}+\mathrm{XB}$ \\
\hline Dry matter & 88.5 & 88 & 88 & 89.2 & 88.6 & 88.8 \\
\hline Crude protein & 22.9 & 22.4 & 22.3 & 22 & 20.6 & 21.1 \\
\hline Crude fibre & 4 & 4.6 & 3.2 & 3.4 & 2.4 & 4.5 \\
\hline Ash & 6.2 & 5.8 & 6.2 & 6.1 & 5.6 & 5.8 \\
\hline Starch & 38.5 & 40 & 40 & 37.8 & 43.2 & 41.8 \\
\hline Ether extract & 5.5 & 4 & 4 & 6.4 & 5 & 5.3 \\
\hline Calcium & 1.07 & 1.07 & 1.08 & 1.07 & 1.05 & 1.07 \\
\hline Sodium & 0.16 & 0.14 & 0.15 & 0.18 & 0.18 & 0.2 \\
\hline Phosphorus & 0.59 & 0.56 & 0.55 & 0.52 & 0.55 & 0.51 \\
\hline Xylanase, XU/kg & $<100$ & ND & 1,458 & ND & 172 & 1,422 \\
\hline Phytase FTU/kg & 645 & 659 & 563 & 795 & 739 & 766 \\
\hline
\end{tabular}

${ }^{1} \mathrm{NC}=$ negative control; $\mathrm{NC}+\mathrm{XB}=$ negative control plus enzyme combination; $\mathrm{PC}=$ positive control.

2 Supplied a dose level of $100 \mathrm{~g} /$ metric tonne to provide 1,220 units of xylanase and 152 units of beta-glucanase per kg feed. Phytase was added to all diets. 
Table 3. Effect of the xylanase - beta-glucanase enzyme combination on broiler growth performance (d 1-35)., ${ }^{1,2}$

\begin{tabular}{|c|c|c|c|c|c|}
\hline Parameter & PC & $\mathrm{NC}$ & $\mathrm{NC}+\mathrm{XB}^{3}$ & SEM & $P$-value \\
\hline \multicolumn{6}{|l|}{ d 1-21 (starter phase) } \\
\hline ADG (g/bird/day) & 40.0 & 39.6 & 40.6 & 0.4 & 0.3 \\
\hline ADFI (g/bird/day) & 58.5 & 59.5 & 61.1 & 1.3 & 0.4 \\
\hline FCR $(\mathrm{g} / \mathrm{g})$ & 1.46 & 1.50 & 1.50 & 0.0 & 0.4 \\
\hline \multicolumn{6}{|l|}{ d 22-35 (finisher phase) } \\
\hline BW (g/bird) & $2,173^{a}$ & $2,085^{b}$ & $2,173^{a}$ & 24.8 & 0.03 \\
\hline ADG (g/bird/day) & $91.8^{\mathrm{a}}$ & $86.3^{b}$ & $90.9^{\mathrm{a}}$ & 1.6 & 0.04 \\
\hline ADFI (g/bird/day) & 152.9 & 151.3 & 152.9 & 1.7 & 0.7 \\
\hline FCR $(\mathrm{g} / \mathrm{g})$ & $1.66^{b}$ & $1.76^{a, x}$ & $1.68^{\mathrm{ab}, \mathrm{y}}$ & 0.02 & 0.03 \\
\hline \multicolumn{6}{|l|}{ d $1-35$ (overall) } \\
\hline ADG (g/bird/day) & $60.6^{\mathrm{a}}$ & $58.3^{b}$ & $60.7^{a}$ & 0.7 & 0.04 \\
\hline ADFI (g/bird/day) & 96.3 & 96.2 & 97.8 & 1.2 & 0.5 \\
\hline FCR $(\mathrm{g} / \mathrm{g})$ & $1.59^{\mathrm{a}}$ & $1.65^{b}$ & $1.61^{\mathrm{ab}}$ & 0.02 & 0.0 \\
\hline FCRc $(\mathrm{g} / \mathrm{g})$ & $1.59^{\mathrm{a}}$ & $1.68^{b}$ & $1.61^{\mathrm{a}}$ & 0.02 & 0.01 \\
\hline Mortality (\%) & 0.0 & 2.31 & 1.9 & 0.8 & 0.13 \\
\hline EPEF & $383.6^{a}$ & $347.9^{b}$ & $378.0^{\mathrm{a}}$ & 5.80 & 0.006 \\
\hline
\end{tabular}

${ }^{1} \mathrm{ADFI}=$ average daily feed intake; $\mathrm{ADG}=$ average daily gain; $\mathrm{BW}=$ body weight; $\mathrm{EPEF}=$ European production efficiency factor; $F C R=$ feed conversion ratio; $F C R c$ = body weight corrected feed conversion ratio, by correction of 3 points for $100 \mathrm{~g} \mathrm{BW}$ difference from PC; NC = negative control; NC+XB = negative control plus enzyme combination; $\mathrm{PC}=$ positive control.

${ }^{2}$ Means in the same row with no common superscripts are significantly different $(P<0.05) ; \mathrm{x}, \mathrm{y}$ means tendency of significant different $(P<0.1)$, based on Dunnett's test. The comparison was made using PC or NC as control.

${ }^{3}$ Supplied a dose level of $100 \mathrm{~g} /$ metric tonne to provide 1,220 units of xylanase and 152 units of beta-glucanase per $\mathrm{kg}$ feed.

same xylanase/beta-glucanase combination used in the present study but supplied at a higher dose level $(2,500 \mathrm{U} / \mathrm{kg}$ xylanase and $250 \mathrm{U} / \mathrm{kg}$ of beta-glucanase). Effects were lower in magnitude on the maize- vs the wheat-based diet, but were still statistically significant. Kiarie et al. (2014) employed the same xylanase as the present study which was supplemented at the same dose level $(1,250 \mathrm{U} / \mathrm{kg})$ in maizevs wheat-based diets, and reported effects of xylanase on FCR (which was reduced vs PC) and BW gain (which was increased vs PC) between d 0-42, independent of diet type. Orthogonal contrasts did not identify any significant improvement in FCR between xylanase supplemented and non-supplemented birds fed maize-soybean meal-based diets in their study, but this may have been because the test diets were nutritionally adequate, rather than energy reduced. Hence, the capacity for improvement by enzymes may not have been as apparent as in the present study (Adeola and Cowieson, 2011).

In the current study, the greater improvement seen in the finisher compared to the starter phase with addition of enzymes could be attributed to the fact that the starter phase diets were less nutritionally deficient than in the finisher phase. Despite this, there is a body of evidence suggesting that xylanase or xylanase/betaglucanase combinations can significantly improve broiler performance in maize-soybean based diets in both starter and/or finisher phases, and the findings of the present study confirm this. In addition, it appears that these enzymes can deliver improvements in growth performance (principally FCR) beyond those that are produced by phytase, since the performance benefits observed in both the current study and that of Masey O'Neill et al. (2012) were evident despite the incorporation of phytase into the basal diets at standard inclusion levels.

In most of the published studies, including the present study, the beneficial effects on performance appeared to be driven by better FCR as a consequence of increased BWG, with no or only marginal effects on FI. This suggested that the enzymes improved nutrient and energy utilisation of the maize-soybean meal-based diets. Indeed, a study by Cowieson et al. (2010) reported improvements in the digestibility of certain nutrients, including nitrogen, ileal digestible energy and certain amino acids, some of which were only evident with the xylanase/beta-glucanase combination (i.e. ileal digestibility of $\mathrm{N}$ and energy), not individually, when compared with NC.

The present study only tested the enzymes in combination, not individually. However, it has been demonstrated that the hemicellulose fraction of soybean meal cell walls contains a significant level of xyloglucans in addition to xylans (Huisman et al., 2000). Therefore, it was expected that the xyloglucan digesting ability of a beta-glucanase in combination with a xylanase could deliver improvements in the digestibility of the fibrous components of the soybean meal over and above those produced by xylanase alone.

The mode of action by which xylanase and beta-glucanase may deliver increased nutrient and energy utilisation in wheat-based diets has been considered at length. A reduction in digesta viscosity and in associated disruptive effects on digestion and absorption processes as a result of the hydrolysis of soluble NSPs by enzymes, and a concurrent increase in short chain fatty acid production 
due to the release of fermentable oligosaccharides, are believed to be major factors (Adeola and Cowieson, 2011). In addition, beneficial effects on gut microbial communities that may indirectly improve nutrient digestion have been cited (Hubener et al., 2002). The mode of action in maizesoybean meal-based diets is less clear. Both maize and soybean meal contain significant quantities of NSPs, but their profile differs, both in terms of composite sugars and solubility under the conditions found in the gastrointestinal tract. In maize, arabinose and xylose content collectively is approximately $4.7 \%$ (DM basis) and beta-glucan content is $0.1 \%$. In soybean meal, the combined content of xylose and glucose is 2.3\% (Bach Knudsen, 2014) and contains beta-glucans of $0.38 \%$ on a DM basis (Danisco Animal Nutrition NSPs database, unpublished) the latter which has been reported as high as $0.6 \%$ (Mathlouthi et al., 2002). In wheat, the ratio between soluble and insoluble NSPs (Choct, 2006) is considerably higher $(0.26: 1)$ than that in soybean meal $(0.16: 1)$ or maize $(0.013: 1)$. The beneficial effects of NSP-degrading enzymes on digesta viscosity in maize-soybean meal-based diets have been reported (Kiarie et al., 2014; Munyaka et al., 2016), but at a lower magnitude than for wheat-based diets. This was presumed to be due to the lower soluble NSP content. Effects on digesta viscosity and nutrient digestibility were not measured in the present study. However, the fact that the $\mathrm{NC}+\mathrm{XB}$ diet, that was reduced in energy, protein and amino acids, recovered performance back to the level of the nutritionally adequate PC diet, suggested that the enzymes enhanced the digestion of NSPs in the fibre component and protein that may be bound to fibre, as a close interaction between fibre and protein has been documented in the literature.

\section{Conclusions}

In a commercial diet containing phytase, supplementation of an energy, protein and amino-acid deficient maizesoybean meal-based diet with an enzyme combination that provided 1,220 U/kg xylanase and $152 \mathrm{U} / \mathrm{kg}$ betaglucanase recovered broiler growth performance back to the level of a nutritionally adequate diet over an entire growth cycle (d 1-35). The enzyme combination improved FCR without impacting FI, which suggested improved nutrient and energy utilisation of the feed matrix.

\section{Acknowledgements}

The authors would like to thank Dr Joelle Buck (Newbury, UK) for her assistance with writing of this manuscript.

\section{Conflict of interest}

This research was funded by Danisco Animal Nutrition (IFF). S. Gilani, Y. Dersjant-Li and K. Gibbs are employees of Danisco Animal Nutrition (IFF). L. Barnard was a formal employee of Danisco Animal Nutrition.

\section{References}

Adeola, O. and Cowieson, A.J., 2011. Opportunities and challenges in using exogenous enzymes to improve non-ruminant animal production. Journal of Animal Science 89: 3189-3218. https://doi. org/10.2527/jas.2010-3715

Amerah, A.M., 2015. Interactions between wheat characteristics and feed enzyme supplementation in broiler diets. Animal Feed Science and Technology 199: 1-9. https://doi.org/10.1016/j. anifeedsci.2014.09.012

Annison, G. and Choct, M., 1991. Anti-nutritive activities of cereal non-starch polysaccharides in broiler diets and strategies for minimizing their effects. World's Poultry Science Journal 47: 232242. https://doi.org/10.1079/WPS19910019

Association of Official Analytical Chemists (AOAC), 2000. Official methods of analysis. $17^{\text {th }}$ edition. The Association of Official Analytical Chemists, Gaithersburg, MD, USA. Methods 925.10, 65.17, 974.24, 992.16.

Aviagen, 2014. Ross 308 Vleeskuiken Standaarden and streefresultaten. Aviagen, Arendonk, Belgium, 16 pp. Available at: https://www. broeierijdavid.be/wp-content/uploads/Vleeskuiken-308-NL-2014. pdf.

Bach Knudsen, K.E., 2011. Effects of polymeric carbohydrates on growth and development in pigs. Journal of Animal Science 89: 1965-1980. https://doi.org/10.2527/jas.2010-3602

Bach Knudsen, K.E., 2014. Fiber and nonstarch polysaccharide content and variation in common crops used in broiler diets. Poultry Science 93: 2380-2393. https://doi.org/10.3382/ps.2014-03902

Bao, Y.M., Romero, L.F. and Cowieson, A.J., 2013. Functional patterns of exogenous enzymes in different feed ingredients. World's Poultry Science Journal 69: 759-772. https://doi:10.1017/ S0043933913000792

Choct, M., 2006. Enzymes for the feed industry: past, present and future. World's Poultry Science Journal 62: 5-15. https://doi. org/10.1079/WPS200480

Choct, M., Dersjant-Li, Y., McLeish, J. and Peisker, M., 2010. Soy oligosaccharides and soluble non-starch polysaccharides: a review of digestion, nutritive and anti-nutritive effects in pigs and poultry. Asian-Australasian Journal of Animal Science 23: 1386-1398. https:// doi.org/10.5713/ajas.2010.90222

Choct, M., Hughes, R.J., Wang, J., Bedford, M.R., Morgan, A.J. and Annison, G., 1996. Increased small intestinal fermentation is partly responsible for the anti-nutritive activity of non-starch polysaccharides in chickens. British Poultry Science 37:609-621. https://doi.org/10.1080/00071669608417891

Cowieson, A.J., Bedford, M.R. and Ravindran, V., 2010. Interactions between xylanase and glucanase in maize-soy-based diets for broilers. British Poultry Science 51: 246-257. https://doi. org/10.1080/00071661003789347

Hubener, K., Vahjen, W. and Simon, O., 2002. Bacteria responses to different dietary cereal types and xylanase supplementation in the intestine of broiler chickens. Archives of Animal Nutrition 56: 167-187. https:// DOI: 10.1080/00039420214191 
Huisman, M.M.H., Schols, H.A. and Voragen, A.G.J., 1998. Cell wall polysaccharides from soybean (glycine max.) meal: isolation and characterisation. Carbohydrate Polymers 37: 87-95. https://doi. org/10.1016/S0144-8617(97)00111-2

Huisman, M.M.H., Weel, K.G.C., Schols, H.A. and Voragen, A.G.J., 2000. Xyloglucan from soybean (Glycine max) meal is composed of XXXG-type building units. Carbohydrate Polymers 42: 185-191. https://doi.org/10.1016/S0144-8617(99)00154-X

Jozefiak, D., Rutkowski, A., Jensen, B.B. and Engberg, R.M., 2006. The effect of beta-glucanase supplementation of barley- and oat-based diets on growth performance and fermentation in broiler chicken gastrointestinal tract. British Poultry Science 47: 57-64. https://doi. org/10.1080/00071660500475145

Kiarie, E., Romero, L.F. and Ravindran, V., 2014. Growth performance, nutrient utilization, and digesta characteristics in broiler chickens fed corn or wheat diets without or with supplemental xylanases. Poultry Science 93: 1186-1196. https://doi.org/10.3382/ps.201303715

Masey O'Neill, H.V., Mathis, G., Lumpkins, B.S. and Bedford, M.R., 2012. The effect of reduced calorie diets, with and without fat, and the use of xylanase on performance characteristics of broilers between 0 and 42 days. Poultry Science 91:1356-1360. https://doi. org/10.3382/ps.2011-01867

Mathlouthi, N., Juin, H. and Larbier, M., 2003. Effect of xylanase and beta-glucanase supplementation of wheat- and barley-based diets on the performance of male turkeys. British Poultry Science 44:291298. https://doi.org/10.1080/0007166031000096498

Mathlouthi, N., Saulnier, L., Quemener, B. and Larbier, M., 2002. Xylanase, $\beta$-glucanase, and other side enzymatic activities have greater effects on the viscosity of several feedstuffs than xylanase and $\beta$-glucanase used alone or in combination. Journal of Agricultural and Food Chemistry 50: 5121-5127. https://doi.org/10.1021/ jf011507b

McNab, J. and Boorman, N. (eds), 2002. Poultry feedstuffs supply, composition, and nutritive value. CAB Publishing. Oxfordshire, UK.
Meng, X., Slominski, A., Nyachoti, C.M., Campbell, L.D. and Guenter, W., 2005. Degradation of cell wall polysaccharides by combinations of carbohydrase enzymes and their effect on nutrient utilization and broiler chicken performance. Poultry Science 84: 37-47. https:// doi.org/10.1093/ps/84.1.37

Munyaka, P.M., Nandha, N.K., Kiarie, E., Nyachoti, C.M. and Khafipour, E., 2016. Impact of combined $\beta$-glucanase and xylanase enzymes on growth performance, nutrients utilization and gut microbiota in broiler chickens fed corn or wheat-based diets. Poultry Science 95: 528-540. https://doi.org/10.3382/ps/pev333

NRC, 1994. Nutrient requirements of poultry. $19^{\text {th }}$ rev. ed. National Academic Press, Washington, DC, USA.

Olukosi, O.A., Bedford, M.R. and Adeola, O., 2007. Xylanase in diets for growing pigs and broiler chicks. Canadian Journal of Animal Science 87: 227-235. https://doi.org/10.4141/CJAS06005

Romero, L.F., Parsons, C.M., Utterback, P.L., Plumstead, P.W. and Ravindran, V., 2013. Comparative effects of dietary carbohydrases without or with protease on the ileal digestibility of energy and amino acids and AMEn in young broilers. Animal Feed Science and Technology 181: 35-44. https://doi.org/10.1016/j. anifeedsci.2013.02.001

Selle, P.H., Ravindran, V. and Partridge, G.G., 2009. Beneficial effects of xylanase and/or phytase inclusions on ileal amino acid digestibility, energy utilization, mineral retention and growth performance in wheat-based broiler diets. Animal Feed Science and Technology 153: 303-313. https://doi.org/10.1016/j.anifeedsci.2009.06.011

Ward, N.E., 2021. Debranching enzymes in corn/soybean meal-based poultry feeds: a review. Poultry Science 100: 765-775. https://doi. org/10.1016/j.psj.2020.10.074

Widyaratne, G.P. and Zijlstra, R.T., 2007. Nutritional value of wheat and corn distiller's dried grain with solubles: digestibility and digestible contents of energy, amino acids and phosphorus, nutrient excretion and growth performance of grower finisher pigs. Canadian Journal of Animal Science 87: 103-114. https://doi.org/10.4141/A05-070 
